\author{
Andrzej Sztylka \\ Uniwersytet Przyrodniczo-Humanistyczny \\ w Siedlcach
}

\title{
Praca jako dzialalność humano-pragmatyczna czynnikiem samorealizacji ludzi
}

Jednym z istotnych problemów, jakie powinny być rozstrzygnięte w związku z problematyką charakteru i orientacji życiowej człowieka, który stawałby się „przedsię-biorcą własnego życia”, a więc jednostką działającą de iure i de facto, jest zagadnie-nie roli, jaką w życiu takiego człowieka ma odgrywać kompetentnie wykonywana praca. Kwestię tę formułuję tutaj w odniesieniu do humano-pragmatycznej orientacji sensu życia, co sprawę może dramatyzuje, ale z drugiej strony istotnie uściśla i organizuje merytoryczne pole rozważania. Tak określona orientacja stanowi szczęśliwe połączenie pierwiastka pragmatycznego, ukazującego sens życia w dobrym funkcjonowaniu, sprawności i opłacalności celów i działań, z pierwiastkiem humanistycznym, wskazującym jako główny wyznacznik sensu życia jednostkę ludzką i świat humanistyczny, będący rzeczywistością przez nią nieustannie odnajdywaną i tworzoną.

Odpowiadając na pytanie o rolę kompetentnie wykonywanej pracy w życiu takiej jednostki ludzkiej, uwzględnimy następujące kwestie:

1. Pracę jako rozwój życia.

2. Pracę jako samourzeczywistnienie.

3. Pracę jako wartość wspierającą i urzeczywistniającą inne wartości humanistyczne.

Jako rozwój życia, praca jest całokształtem działalności (a więc wszystkim, co człowiek robi celowo i sensownie rozwijając się) w zakresie autokreacji i samopotwierdzenia, w zakresie tworzenia ładu społecznego i wartości przyrody, cywilizacji i kultury. Sensownie planując czynności i działania i wykonując je, taki człowiek ukierunkowuje je w ten sposób, aby były one dla kogoś, a nie same dla siebie ważne. Praca jako rozwój życia nie jest ważna dla samej pracy, ale ma znaczenie o tyle, o ile kogoś cieszy, wzbogaca, kształci, rozwija, o ile korzysta na tym przyroda i wzmacniana jest kultura. Postawa typu ,pracować, aby pracować" stwarza błędne koło, w którym wszelka niegodziwość, chamskie dorobkiewiczostwo i niszczenie „substancji ludzkiej” (np. poniżanie własnych dzieci przez 
pozbawianie ich możliwości rozwoju uczuciowego) oraz niszczenie środowiska naturalnego mogą być wyjaśniane pozornie zbożnym trudem i ucieczką w pracę, w „brak czasu” dla ludzi, rzeczy i spraw, na które czas obecnie musi się znajdować, abyśmy w miarę zdrowi mogli dożyć roku 2012, a nawet trochę dłużej.

Praca jest samourzeczywistnieniem wówczas, gdy, po pierwsze, najważniejsze jest to, co człowiek robi mając na uwadze potrzeby innych ludzi, potrzeby przyrody i kultury. Warto uświadomić sobie, że niejednokrotnie potrzeby ludzi i ich pragnienia nie odpowiadają sobie w części lub nawet w całości. Pragnienia, czyli to, czego człowiek chce, mogą - wskutek zachwiania hierarchii i charakteru potrzeb ludzkich - nie prowadzić do uzupełnienia w organizmie człowieka i w sposobie jego życia różnych braków, na które składają się substancje wartościowemu człowiekowi niezbędne. Potrzeby ludzkie, to zapotrzebowanie na bycie pełnym człowiekiem na Ziemi, na bycie , istotą kulturalną”. Pragnienia zaś, to tutaj i teraz różnorakie i z różnych powodów pojawiające się bieżące pożądania. Nie zawsze to, czego pożądamy, buduje nas jako ludzi. Dlatego warunkiem pracy jako samourzeczywistnienia jest osoba pracująca jako człowiek wolny, który w swej działalności realizuje uzdolnienia i talenty zgodnie z zainteresowaniami i rozeznaniem ogólnej sytuacji kulturowo-cywilizacyjnej oraz potrzeb i warunków kraju, w którym przyszło mu żyć i pracować.

Poruszając problem pracy jako samourzeczywistnienia warto zauważyć, że obecnie granica między czasem pracy a czasem wolnym jest coraz bardziej płynna i umowna, ponieważ praca może stawać się nie tylko bardziej zniewolona, ale również bardziej samorzutna. W tym drugim przypadku możemy zapytać, czy robienie czegoś, co jest ważne, ciekawe, zgodne ze zdolnościami i zamiłowaniem, jest czasem pracy czy czasem wolnym?

Mówiąc, że praca stanowi wartość wspierającą i urzeczywistniającą inne wartości humanistyczne, koncentrujemy się na następujących zagadnieniach:

1. Praca wspiera i tworzy godność ludzką, a więc rozwija refleksję człowieka nad sobą samym i nad rzeczywistością go otaczającą;

2. Praca pozwala ustalić związek z samym sobą, odpowiadać na pytanie „kim jestem i co ja tu robię", a poza tym dlaczego tak naprawdę pracuję, co to komu daje i w którym miejscu społecznym i ,pod kątem ogólnoeuropejskim” naprawdę się znajduję;

3. Praca tworzy „honor zawodowy”, wyrażający się przede wszystkim w świadomym podchodzeniu do wykonywanych zajęć i w „wiedzącym czego oczekiwać", ale równocześnie pełnym dobrej woli, a nawet zawierającym element entuzjazmu, przekonaniu o słuszności wybranego zawodu';

\footnotetext{
${ }^{1} \mathrm{~W}$ rozprawie pt. Ograniczenie człowieka Stefan Szuman pisał: „Entuzjazmem nazywam głęboki zachwyt, wielką życzliwość, serdeczne oddanie dobrej sprawie życia. Życie jest ciężką walką, która nigdy nie jest przegraną, póki istnieje entuzjazm”. S. Szuman, Poważne i pogodne zagadnienia afirmacji życia, Katowice 1947, s. 31.
} 
4. Praca świadomie wybrana i realizowana wzbudza, rozwija oraz dyscyplinuje elementarne poczucie sprawiedliwości, które - właśnie dla fachowca dysponującego równocześnie dobrym wykształceniem ogólnym - nigdy nie oznacza arytmetycznej równości ani jednakowości, a właśnie poczucie współzależności i odpowiedniości między tym, co trzeba aby było dobre dla wszystkich - i indywidualnej w tym roli konkretnej, pracującej jednostki;

5. Praca, którą dana jednostka wykonuje, bo tak zdecydowała i tego chce, tworzy i umacnia odwagę cywilną tej jednostki;

6. Humanistyczna, godnościowa samorealizacja przez pracę jest jednym z podstawowych czynników istnienia niezależności duchowej człowieka, jego wolności stanowienia o sobie samym;

7. Stanowiąca nieodzowny składnik rozwoju kulturalnego jednostki i grup ludzkich praca człowieka wolnego prowadzi ku powstawaniu społeczeństw demokratycznych, ma też duże znaczenie dla rozwoju poczucia demokratyczności w życiu osobistym²;

8. Samodzielnie realizowana praca człowieka, będąca wyrazem jego wolności, stanowi podstawę podejmowania osobowej odpowiedzialności, umożliwiającej postrzeganie swojego życia jako istnienia wplecionego w świat własnych planów, marzeń, oczekiwań, działań podjętych i działań zaniechanych, równocześnie zaś tworzy pewną szczególną wspólnotę takiego życia z życiem innych ludzi, postępowania wobec nich i wobec siebie razem z nimi, również wspólnotę z całym światem przyrody. Czy dana jednostka może uważać się za uczciwego człowieka, jeśli wykonuje pracę, która bardziej zanieczyszcza środowisko niż tworzy coś dobrego? Taka praca ustanawia wreszcie wspólnotę z rzeczywistością kulturalną jednostki ludzkiej i całej cywilizacji. Czy dzięki swojej pracy i przez tę pracę jednostka ludzka staje się lepsza - dla samej siebie, dla innych ludzi, ale także dla lasów i pól wytwarzających żywność, także dla rozumienia dóbr sztuki - czy jednostka taka staje się obojętna lub właściwie gorsza, bo się degraduje moralnie, fizycznie, kulturalnie?

${ }^{2}$ Termin „demokratyczność” ma w humanizmie zastosowanie szczególne, inne niż w koncepcjach religijnej, liberalistycznej czy utylitarystycznej. Z pewnością zastosowanie to ma raczej kulturalny niż polityczny - we współczesnym rozumieniu - charakter. Taka „demokratyczność” ma ogromną wagę dla życia osobistego ludzi i tworzenia się społeczeństw kulturalnych ze względu na kwestię typów ich uczestnictwa w trwałych wartościach humanistycznych. Precyzując więc tu humano-pragmatyczne rozumienie kwestii demokratyczności, stwierdzę, iż oznacza ona: (1) wolność w odróżnieniu nie od niewoli, ale od samowoli; (2) równość, ale nie jednakowość czy przeciętność, a prawo każdego do rozwoju humanistycznego; (3) odpowiedniość wzajemną ludzi, rzeczy i stosunków - w odróżnieniu od jednakowości; (4) współdziałanie w odróżnieniu od współzawodnictwa wartości słuszne, potrzebne itd., wspierające się wzajemnie, stają się silniejsze jedna dzięki drugiej, są silne obydwie; mechanizm wspierania dobra o dobro jest czymś doskonalszym niż mechanizm walki dóbr; (5) kompetencję osobistą i grupową zapobiegające manipulacjom; (6) wzajemne poszanowanie wynikające z kierowania się w życiu etyką niezależną, czyli etyką humanistyczną. 
Taki godnościowy charakter pracy prowadzi człowieka ku wspólnocie wartości pracy i wartości ludzi, tworzy sens życia. W życiu osobistym takiego człowieka istnieje miłość, która przez zamiłowanie przeradza się w życiu zawodowym $\mathrm{w}$ dążenie do mistrzostwa. Ujawnia się też rola sensownego cierpienia: praca wynikająca z wolności i godności ukazuje znaczenie niezbędnego trudu, dokładności, rzetelności, a również wyrzeczenia, cierpliwości i wyrozumiałości w dochodzeniu do celu, w codziennym życiu, wobec innych ludzi. Tak wytwarzają się subtelne uczucia wyższe - bezinteresowność, harmonia, wierność naturze, wiara i doskonałość. Uczucia te tworzą w człowieku pewne piękne poczucie moralnej prostoty, tak ważne w podejmowaniu decyzji, co jest w życiu słuszne, a co niesłuszne. Wartościowy udział w życiu i satysfakcja z tego udziału stwarzają podstawę, a zarazem perspektywy szczęścia. 